УДК 811.111-26+316.77

\title{
МЕМЫ КАК СРЕДСТВО ОБЩЕНИЯ И СОЗДАНИЯ НАСТРОЕНИЯ КОММУНИКАНТОВ
}

\author{
Лихонина Юлия Тимуровна \\ Любимцева Екатерина Михайловна \\ Лещенко Анна Александровна \\ Научный руководитель: Мкртчян Тамара Юрьевна \\ к.ф.н., доцент \\ Южный федеральный университет
}

\begin{abstract}
Аннотация: Статья посвящена исследованию мема как популярной коммуникативной единицы современного интернет-общения, его воздействующей силе при формировании настроения и мнения Интернеткоммуникантов. Авторы рассматривают понятие «мем», останавливаются на межкультурных особенностях и уникальных культурных особенности англоязычных Интернет-мемов, проводят классификационный анализ креолизованных англоязычных Интернет-мемов 2020 года, обращаются к сферам применения мемов и их воздействующему потенциалу на примере новейших англоязычных мемов.
\end{abstract}

Ключевые слова: мем; Интернет-пространство; межкультурная коммуникация; концепт; СМИ; маркетинг; манипулятивное воздействие.

\section{MEMES AS A MEANS OF COMMUNICATION AND CREATING THE MOOD OF COMMUNICATORS}

\author{
Likhonina Julia Timurovna \\ Lyubimtseva Ekaterina Mikhailovna \\ Leshchenko Anna Aleksandrovna \\ Scientific adviser: Mkrtchyan Tamara Yurievna
}

\begin{abstract}
The article is devoted to the study of the meme as a popular communicative unit of modern Internet communication, its influencing force in the formation of the mood and opinion of Internet communicators. The authors consider the term «meme», dwell on cross-cultural peculiarities and culturally specific features of English Internet memes, carry out classification of present-day creolized English


memes, consider the scope of English memes and refer to the impacting potential of memes using the example of the latest English-language memes.

Key words: meme, the Internet space, intercultural communication, creolized memes, mass media, marketing, manipulative influence.

Internet memes are an essential part of our daily communication. Even though the phenomenon is quite recent, it has rapidly become widespread and popular. Memes quickly attract Internet users' attention in such enormous data flow; it is quite hard to find a modern user who doesn't use them in conversations with friends, family or even colleagues online. However, despite its popularity and relevance nowadays, the phenomenon of Internet memes still remains understudied and obscure. Memes not only produce a comic effect and have an emotional impact on both the sender and the recipient, but also influence many spheres of our society: they help to express public sentiment from all directions and all angles. That is why studying of the meme as an important tool of interlingual and intercultural communication is becoming topical for many modern linguistic researches.

The aim of the article is to consider the term «meme», dwell on cross-cultural peculiarities and culturally specific features of Internet memes, carry out classification of present-day creolized English memes, consider the spheres of English meme application and refer to the impacting potential of memes using the example of the latest English-language memes.

There is no academic definition for the term under analysis in linguistics yet. Dictionary.com [1, dictionary.com] claims a meme to be «a cultural item in the form of an image, video, phrase, etc., that is spread via the Internet and often altered in a creative or humorous way». Another definition of a meme states that it is «an amusing or interesting item (such as a captioned picture or video) or genre of items that is spread widely online especially through social media» [2, merriamwebster.com]. Thus, an Internet meme is viewed at as an activity, concept, catchphrase, or piece of media that spreads from an individual to an individual via the Internet by means of informal communities, online magazines, direct messages via different messenger apps such as WhatsApp or Telegram, or even news sources.

It must be stressed that what is meant by a meme may differ across various Internet communities. Furthermore, a meme is liable to change throughout time. Traditionally, a meme consists of an image or a combination of images and a sarcastic or humorous phrase. However, the concept has since become more extensive and multi-faceted. It evolves to more complicated structures, for instance, 
GIFs, videos, etc. Memes always relay more significant and exciting information or knowledge that a simple text alone can't transfer [3, academic.oup.com]. The Internet meme does not seek accurate reproduction, but is aimed to distort, or at least to create new contexts in the broad sense of the word. Its appearance is often unexpected, and sometimes meaningless and absurd.

The term «meme» comes from the Ancient Greek word mimema and means «imitated thing». This word was invented by the British evolutionary biologist Richard Dawkins in his work «The Selfish Gene» in 1976 as an idea for explaining evolutionary mechanisms in the spread of ideas and cultural phenomena [4, wikipedia.org]. R. Dawkins used this term to refer to any cultural object which might be considered an imitation, suggesting that a person could view many cultural objects as replicators. Examples of memes in Dawkins' theory include particular signifiers such as melodies, catchphrases, and clothing fashions [3, academic.oup.com]. Memes generally spread through exposure to humans, who are able to copy any information or behavior. However, memes may change after a while as humans do not always copy them accurately, but modify, conjoin and improve them to create some new ones. Memes can be transmitted only through senses; therefore, their transmission requires a physical carrier, such as photons, sound waves, touch, taste, or smell [4, wikipedia.org].

Analysis of Internet memes has shown that they can act as a means of crosscultural communication. Firstly, it is confirmed by the fact that the main language used in Internet memes is English. English as a means of international communication in Internet memes greatly simplifies the application of Internet memes by users who may belong to different cultures and at the same time can join the global Internet culture without experiencing a language barrier. In addition, the high potential of Internet memes as a means of cross-cultural interaction is reflected in the fact that Internet memes reflect the process of globalization of cultural and informational content [5, britannica.com].

The identity of Internet memes in different languages means that Internet users belonging to different cultures consume similar Internet content, therefore become adherents of unified cultural values propagated through the Internet, which in turn reflects the broad process of globalization. In order to adapt Internet memes for the local Internet user, the accompanying inscription of the Internet meme is often modified during translation, and concepts that are alien to the local culture can be replaced with familiar, easily recognizable concepts. The trend to adapt globalized English-language Internet content for local Internet users reflects the widespread 
process of glocalization - changing of globalized content to suit local specifics [6, c. 562-586].

Culturally specific features of Internet memes show that they are heavily influenced by national culture, that is, there is a certain opposition between global trends in Internet communication and culturally determined local differences. These observations allow us to conclude that Internet memes reflect the process of localization - the process of spreading local differences as opposed to global trends, becoming a storage of cultural signs [7, c. 606-612].

All Internet memes can be classified into five types: text memes, picture memes, video memes, gifs and creolized memes [8, c. 68]. The point of our interest and further research is a creolized meme. A creolized meme is a type of creolized text, the unity of verbal and nonverbal constituents (text and image), which can be changed by users while maintaining the semantic value of the meme.

According to the type of relation between the image and the text constituents, three basic groups of creolized memes can be distinguished:

1) zero creolized memes (the visual part is not included; the verbal part is considered as the main idea or element).

2) fully creolized memes, which are subdivided into dominant illustration memes (the verbal piece refers to the visual and cannot exist separately) and equivalent illustration memes (both visual and verbal pieces contain the same amount of information).

3) partially creolized memes, which fall into decorative images (the visual is unnecessary while the verbal part can exist independently) and accompanying illustration (the visual piece complements the verbal and eases its understanding) [9, c. 199].

According to their semantic meaning creolized memes fall into comic memes, advice memes, motivators and demotivators [10, c. 54]. Comic memes are a series of drawings inside boxes that tell a story through pictures and are often published in newspapers or magazines [11, oxfordlearnersdictionaries.com]. Advice memes are a category of memes-pictures with different animals or characters on a colored background. Witty phrases that are uttered by the character in the centre are placed at the top and bottom of the picture [12, c. 70]. Motivators are memes as pictures or photos in a light frame under which there is some motivating, inspiring slogan and its explanation. Most religious slogans, mottos against smoking, alcohol, etc. are made in the form of motivators. The motivator has a philosophical approach and a semantic value $[12$, c. 71$]$. Demotivators are pictures in a dark-colored frame that are the 
opposite of motivators. In terms of meaning, the demotivator is characterized by hopelessness and despair. It has a negative meaning or contains black humor $[12$, c. 72$]$.

Memes enjoy high popularity nowadays. There are many spheres where they are used: marketing, politics, media, everyday life, etc. Let's consider the three basic spheres.

\section{Meme as an object of political discourse:}

Political memes have become viral since 2016 in USA during president election. This type of meme shows the people's reaction on actual situations in the country or in the whole world. What is interesting about political memes is that they not only represent the reaction of society on some topics but affect the consciousness of the recipients. Being anonymous, such memes share the possibility to express individual's point of view freely and independently. The most popular figure of American political memes in 2020 became the US president Donald Trump (picture 1) [13, c. 26-28].

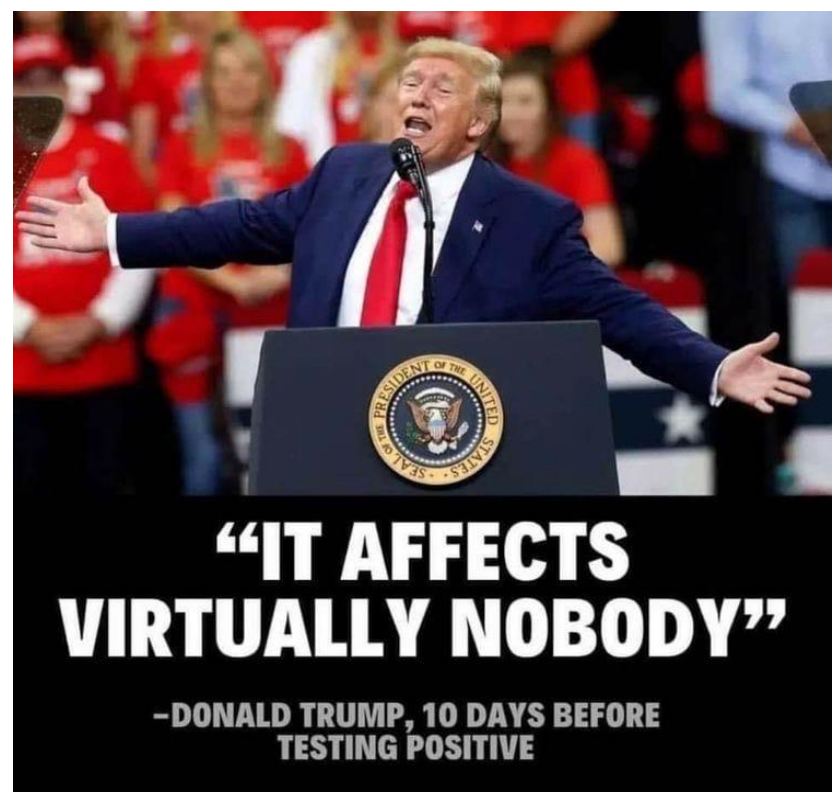

Picture 1. Trump meme

\section{Meme in the media context:}

The realization of memes by the media is very profitable. Most often, memes in official media take an important place in stories or articles. Memes that are recognizable among Internet users stir up interest in particular problems. Applying photos, infographics, and drawings not only speeds up and simplifies the perception of information, but also allows journalists to focus the reader's attention on certain elements of the message and highlight the most important, in the author's opinion, 
issues. Visualization helps compensate for information drawbacks, and through the interaction of visual and verbal components of the text, various meanings significant for communication are formed.

For example, Greta Thunberg, a well-known environmental activist, became a meme because of her behavior (picture 2). She used to challenge world leaders to take immediate actions against climate change. Her phrase "you have stolen my dreams and my childhood" became a meme, as Greta's personality on the whole [14, c. 135-141].

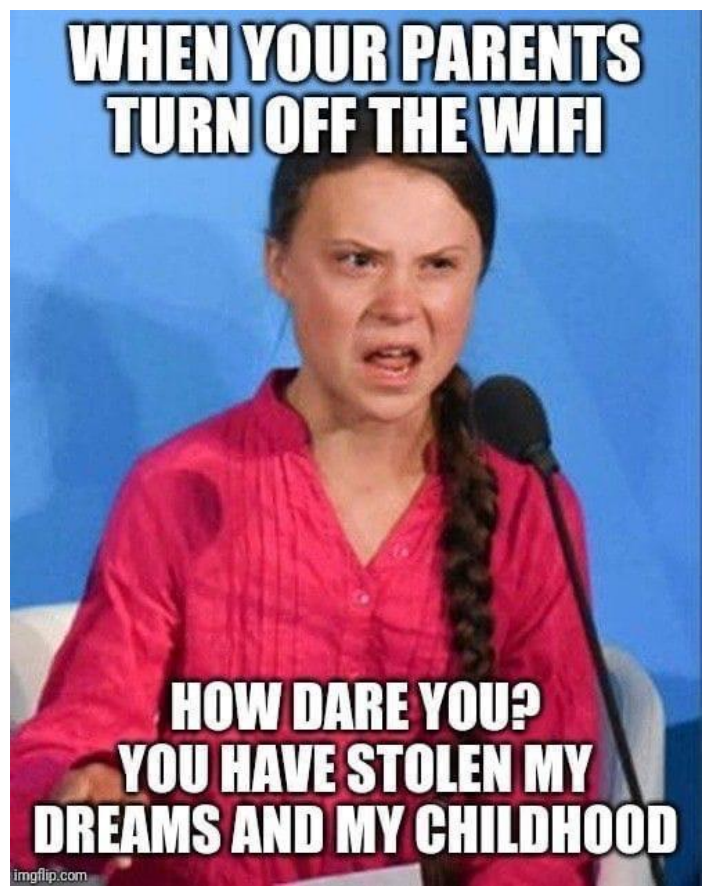

Picture 2. Greta Thunberg meme

\section{Meme in marketing:}

A meme is a symbol of an idea that everyone can understand. Thus, marketing messages formulated in the form of memes quickly and easily convey information about the benefits of a product or service to consumers. Such meme characteristics as visualization, speed and simplicity in creation, ease of recognition and breadth of distribution can be used to create a teaser, a billboard, a poster, a banner, and even a TV commercial.

Due to their comic effect and memorability, Internet memes are increasingly used in advertising communication today. Audience engagement and their willingness to interact with the brand helps to build two-way communication that is beneficial for manufacturers of goods and services. Today, the goal of a marketer is to give a brand a memetic power.

For instance, the "Ruffles", brand of potato crisps, used meme as an advertisement (picture 3) [15, c. 53-57]. 


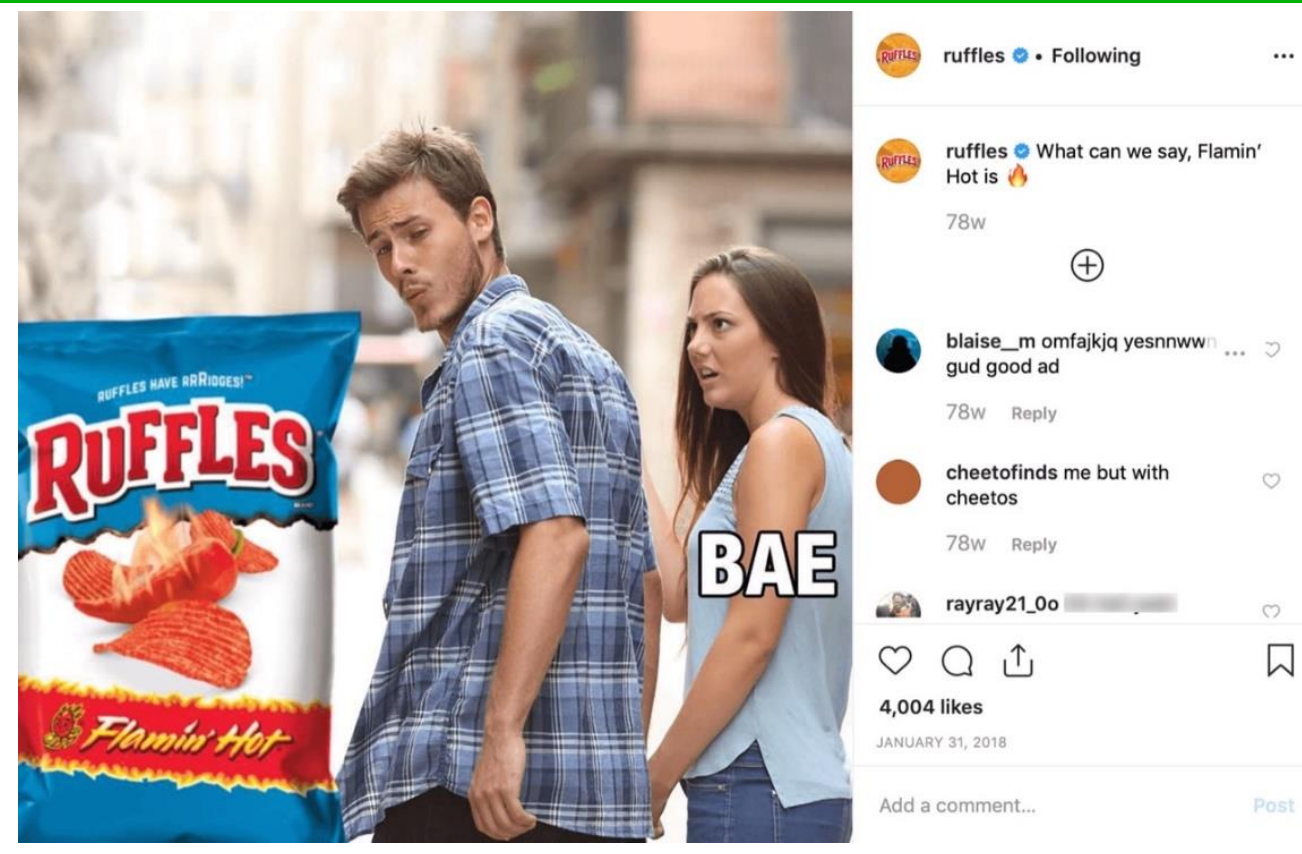

Picture 3. The "Ruffles" meme

\section{The Impact of Memes on the Internet Users}

There are many various ideas about the impact of memes on people - it is positive, neutral, or negative. According to some scholars, memes may be seen as being inherently harmful, since they are viruses of the mind; once assimilated into the human mind, their main purpose becomes their own replication, with humans having almost no control over them. Some memes, however, are beneficial but can become dangerous: after they have been seeded in the human mind, they may lend themselves to being misused or abused. For instance, although memes based on some religious or political ideas may benefit the people who carry them, the same memes may be hurtful and offensive to people whose religious or political views are different [5, britannica.com].

By creating and transmitting memes, the user reconstructs and transmits his worldview to the Internet community, thereby making it public, strengthening the corresponding positions of other users. If his experiences find a response, the meme continues to be transmitted. This exchange of views supports the unity of the community and the strengthening of common and individual significant systems. Thus, the exchange of memes affects both the formation of and addition to a social and individual picture of the world [16, c. 195].

By understanding and transmitting memes, the users establish their identity and associate themselves with the community of «initiates». In addition, the user may not participate in the life of the Internet community, not take part in discussions, but by consuming Internet memes that circulate in it, he already becomes a part of it. 
Therefore, simply viewing memes gives the illusion of belonging to the community [16, c. 196].

Internet memes are democratic in transmission. They are placed in public places - public pages, forums, and image boards. There they can be placed or copied or transferred from one user to another one [16, c. 196].

A meme idea focuses on an event from the past, a recent news item, or an idea. Then, the creative process begins with the use of various existing memes that match the meaning. A single event can reflect a whole galaxy of different memes. As a result, the user gets an interpretation of a particular idea through different memes. Already learned meanings of memes make you look at the event from one angle or another [16, c. 195-200].

As a result, we conducted a study of the meme as a popular communicative unit of today's Internet communication and its influence on the formation of the mood and opinion of Internet communicants. Also, we examined the origin and history of the concept of «meme», focused on the most popular English-language memes, turned to the areas of application of memes and their impact potential according to the example of the latest English-language memes. To sum up, memes are an essential part of our present-day life as they not only have a strong influence on the opinion and mood of communicators, but also have many spheres of application.

\section{References}

1. Онлайн-словарь Dictionary.com [Электронный ресурс]. - Режим доступа: http://dictionary.com (дата обращения: 12.01.2021).

2. Онлайн-словарь Merriam-Webster [Электронный pecypc]. Режим доступа: https://www.merriam-webster.com/ (дата обращения: 12.01.2021).

3. Онлайн-сборник журналов Oxford Academic [Электронный pecypc]. Режим доступа: https://academic.oup.com/journals (дата обращения: 14.01.2021).

4. Онлайн-энциклопедия Wikipedia The Free Encyclopedia [Электронный peсурс]. Режим доступа: https://en.wikipedia.org/wiki/Meme (дата обращения: 14.01.2021).

5. Онлайн-энциклопедия Britannica [Электронный ресурс]. Режим доступа: https://www.britannica.com (дата обращения: 15.01.2021).

6. Sara Cannizzaro Internet memes as internet signs: A semiotic view of digital culture // Sign Systems Studies 44(4). - Lincoln: 2016. - C. 562-586.

7. Канашина С.В. Интернет-мем в контексте межкультурной коммуникации // Новые измерения в лингвистике и лингводидактике: сб. науч. трудов. - Москва: Магия ИННО, 2017. - С. 606-612. 
8. Бабикова М.Р. Жанровые разновидности интернет-мемов в современном националистическом дискурсе // Екатеринбург: Уральский федеральный университет, 2019. - С. 67-73.

9. Шураева А.С., Ю.В. Кузина. Языковая игра в англоязычном комическом креолизованном тексте (на примере интернет-мемов) // Язык в сфере профессиональной коммуникации : сборник материалов международной научно-практической конференции преподавателей, аспирантов и студентов Екатеринбург : ООО «Издательский Дом «Ажур», 2019. - С. 197-202.

10. Лукьянчикова М.В., Бердникова Э.Н. Специфика использования интернет-мемов в маркетинговых целях // Санкт-Петербургский гуманитарный университет профсоюзов, Санкт-Петербург: 2017. - С. 53-57.

11. Онлайн-словарь Oxford Learner's Dictionaries [Электронный ресурс]. Режим доступа: https://www.oxfordlearnersdictionaries.com (дата обращения: 02.02.2021).

12. Бабикова М.Р. Жанровые разновидности интернет-мемов в современном националистическом дискурсе // Екатеринбург: Уральский федеральный университет, 2019. - С. 67-73.

13. Манухина И.А. Мем как объект политического дискурса // Материалы международной научно-практической конференции - Алтай: 2018. - С. 26-28.

14. Голованова Е.И., Часовский Н.В. Интернет-мем как элемент визуализации в СМИ // Вестник Челябинского государственного университета. - Челябинск: 2015. - Вып. 94. - С. 135-141.

15. Лукьянчикова М.В., Бердникова Э.Н. Специфика использования интернет-мемов в маркетинговых целях // Санкт-Петербургский гуманитарный университет профсоюзов, - Санкт-Петербург: 2017. - С. 53-57.

16. Зиновьева Н.А. Воздействие мемов на Интернет-пользователей: типология Интернет-мемов // Вестник экономики, права и социологии - №1, Санкт-Петербург: 2015. - С. 195-200.

(C) Ю.Т. Лихонина, Е.М. Любимцева, А.А. Лещенко, 2021 